\title{
炭素の $\mathrm{CO}_{2}$ ガス反応に伴う微細組織の変化
}

\author{
古田毅·山下安正·白石 稔
}

(平成元年 7 月 14 日受理)

\section{Microtextural Change in Carbons by Reaction with $\mathrm{CO}_{2}$ Gas}

T. Furuta, Y. Yamashita and M. Shiraishi

National Research Institute for Pollution and Resources

16-3 Onogawa, Tsukuba, 305 Japan

The microtextures of carbons reacted at $900^{\circ} \mathrm{C}$ with $\mathrm{CO}_{2}$ gas were studied to obtain a basic information on a relation between reactivity and structure of the carbons. A porous non-graphitizable PF sample has higher reactivity, while a typical lamellar graphitizable carbon, $\mathrm{Ku}$, shows lower reactivity of about $60 \%$ for that of $\mathrm{PF}$. The reaction rates of carbons heat-treated at $2800^{\circ} \mathrm{C}$ were about $40 \%$ of those heat-treated at $1200^{\circ} \mathrm{C}$.

It is found from TEM observation that the oxidation of PF sample proceeds homogeneously in microscopic range. The carbon surface became remarkably rough with development of pores by the oxidation, and altered to a lean and more open microtexture with pore diameters from several to $200 \mathrm{~nm}$. It is observed for $\mathrm{Ku}$ sample that the edge planes react more faster than the basal planes. As the reaction of the carbon with $\mathrm{CO}_{2}$ gas proceeds, elliptical pores between the layer stacks appeared and the ordering of layer stacking decreased to a short range and then disappeared completely to form the porous microtexture of lean nonstacked layers as seen in PF sample reacted severely. It is presumed that $\mathrm{Ku}$ sample shows such a high reactivity as PF sample if entirely transformed from the anisotropic to the porous isotropic microtexture.

KEYWORDS: Carbon, Microtexture, Reaction with $\mathrm{CO}_{2}$, Reactivity.

\section{1.はじめに}

炭素材料は工業材料として必須のあのの一つになって いるが、酸化反応速度がかなり大きいととが欠点の一つ である。黒鉛について P. L. Walker ら ${ }^{1)}$ はガス化反応 を詳細に研究し, その反応機構を論じている。また, 黒 鉛結晶の端面がその基底面より反応性が非常に高いとと あ知られている2)。一方, 酸化反応に伴う形体や組織の 変化は, その炭素材料の機械的性質等に大きく影響する ことから, 原子炉用黒鉛や各種炭素材について主として 走查型電子顕微鏡（SEM）観察が多くなされている3), 公害資源研究所 : $\mathbf{T} 305$ つくば市小野川16-3
4)。しかし，てのような目的のためには，より微視的領 域における構造変化を知ることが耐酸化性に優れた炭素 材料を製造するための基礎的研究としては重要である。 ここでは炭素の微細組織と酸化反応性の関連性を明らか にすることを目的とし, 反応の進行に伴う微細組織の変 化を観察した。

\section{2. 実験}

\section{1 試 料}

フェノール樹脂 (PF) および呉羽化学工業(株)製原 油高温熱分解ピッチのピリジン可溶分 $(\mathrm{Ku})$ をアルゴン 雺囲気中で 1200 および $2800^{\circ} \mathrm{C}$ 亿熱処理して作成した炭 
素を試料として用いた。また, $2800^{\circ} \mathrm{C}$ 処理試料には熱 安定性乱層構造の炭素材である TS力ーボン ${ }^{5)}$ あ加えた。 $2800^{\circ} \mathrm{C}$ 処理試料の $\mathrm{X}$ 線パラメー夕を Table 1 亿示す。

Table 1 X-ray diffraction parameters of carbons heat-treated at $2800^{\circ} \mathrm{C}$.

\begin{tabular}{lcrr}
\hline & $\begin{array}{c}d_{\text {o02 }} \\
\mathrm{nm}\end{array}$ & $\begin{array}{c}L(002) \\
\mathrm{nm}\end{array}$ & $\begin{array}{c}L_{\mathrm{a}}(110) \\
\mathrm{nm}\end{array}$ \\
\hline PF-28 & 0.343 & 3 & 7 \\
TS-28 & 0.342 & 11 & 11 \\
KU-28 & 0.336 & 80 & 100 \\
\hline
\end{tabular}

試料名の前半は出発物質を, 後半の数字は $100^{\circ} \mathrm{C}$ 単位の 処理温度を表す。なお，ヘリウムおよび水銀を置換体之 した比容積から求めた細孔容積は, PF-12 抢よび Ku12 でそれぞれ0.19, $0.09 \mathrm{ml} / \mathrm{g}$ であった。また, $2800^{\circ} \mathrm{C}$ 処理試料を $\mathrm{CO}_{2}$ ガスで測定した平均細孔容積は非常に 小さく, PF-28, TS-28 拉よび Ku-28 の值はそれぞれ $2,1,0 \mathrm{ml} / \mathrm{g}$ であった。

\section{2 酸化反応}

$900^{\circ} \mathrm{C}$ に掞いて $\mathrm{CO}_{2}$ ガスとの反応量の時間変化を測 定した。Fig. 1 亿示す反応装置を用い, $44 \mu \mathrm{m}$ 以下に粉

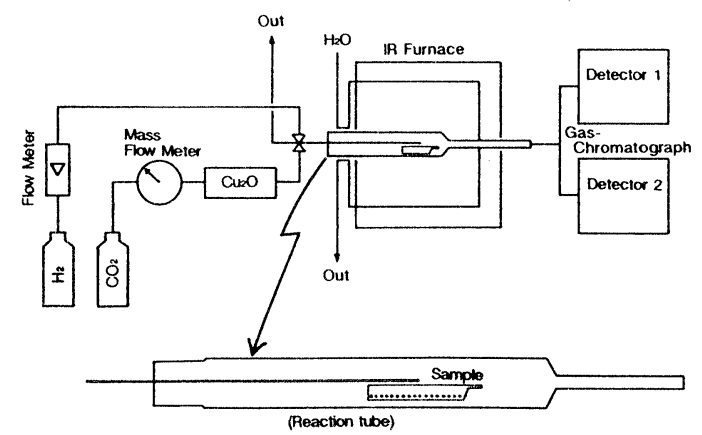

Fig. 1 Schematic diagram of the apparatus used for reaction with $\mathrm{CO}_{2}$.

砕した試料約 $10 \mathrm{mg}$ を高純度アルミナボート面上の $0.7 \times$ $3 \mathrm{~mm}$ 程度の広さの部分に平均的に分散させ, このボー 卜を赤外線炉中の石英反応管 (内径 $24.5 \mathrm{~mm}$ ) に入れる。 高純度 $\mathrm{N}_{2}$ ガス気流中で $900^{\circ} \mathrm{C}$ まで $10^{\circ} \mathrm{C} / \mathrm{min}$ で昇温し， $\mathrm{N}_{2}$ ガスを $\mathrm{CO}_{2}$ ガスに切り替えて, $900^{\circ} \mathrm{C}$ 亿保持した。 $\mathrm{CO}_{2}$ ガスの流速は $100 \mathrm{ml} / \mathrm{min}$ (常温)である。反応量は 発生した CO ガスをガスクロマトグラフで定量して求め た。また, 反応速度 $R(\mathrm{~g} / \mathrm{min} \cdot \mathrm{g})$ は次式から求めた。

$$
R=\frac{1}{w} \cdot \frac{\mathrm{d} w}{\mathrm{~d} t}=\frac{1}{w_{0}(1-B O / 100)} \cdot \frac{\mathrm{d} w}{\mathrm{~d} t}
$$

ここで, $w_{0}$ は試料の未反応時の重量, $w$ は $t$ 分反応後の 重量, $B O$ は $t$ 分反応後の酸化率パーセントである。

\section{3 構造観察}

反応前後の試料を粉砕などの特別の処理をせずに, 微 粒子外形等の変化を SEM (日本電子製 XMA-733) で, 微細組織を透過型電子顕微鏡 TEM（日立製作所製 H$500 \mathrm{H}$ およびフィリップ社製 CM- 30) で観察した。2 800 ${ }^{\circ} \mathrm{C}$ 処理試料についてはラマン分光スペクトルを日本電 子(株)製 JRS-400T を用いて测定した。

\section{3. 結果および考察}

\section{$3.1 \mathrm{CO}_{2}$ 反応}

Fig. 2 に PF-12, Ku-12 についての酸化率および反 応速度 $R$ の反忘時間に伴う変化を示した。酸化率の速

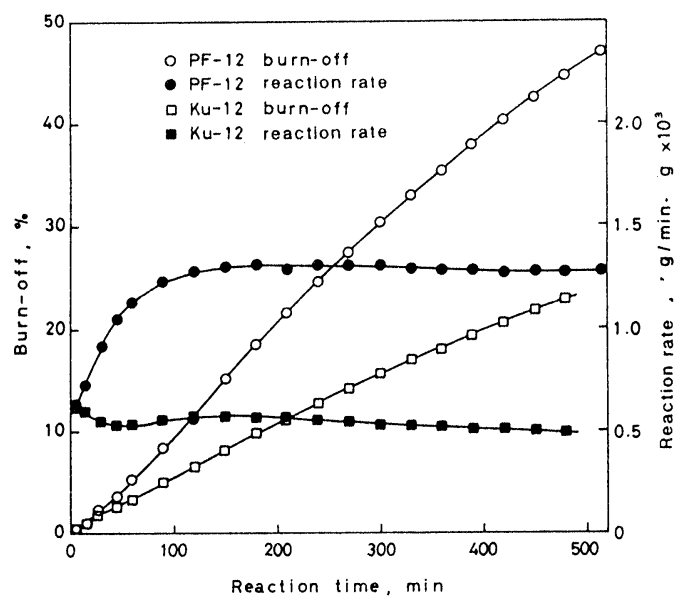

Fig. 2 Changes of burn-off and reaction rate with reaction time for carbons heattreated at $1200^{\circ} \mathrm{C}$.

さはPF-12の方が Ku-12より大きく, 480 分の反応によ ってそれぞれ45,23\%の重量減少があった。PF-12のR は反応時間 100 分まで上昇し, その後はほぼ一定值の $13 \times 10^{-4} \mathrm{~g} / \mathrm{min} \cdot \mathrm{g}$ を示した。一方, Ku-12 は PF-12の 約半分の反応速度を示し, $6 \sim 5 \times 10^{-4} \mathrm{~g} / \mathrm{min} \cdot \mathrm{g}$ であっ た。

$2800^{\circ} \mathrm{C}$ 処理試料では反応性は小さくなり, Fig. 3 亿示 すように480 分後の酸化率は PF-28, TS-28, Ku-28で それぞれ $20,14,8.8 \%$ であり, $1200^{\circ} \mathrm{C}$ 処理試料の約 40 \%であった。反応速度は各試料とも約 200 分以上でほぼ 一定になり，PF-28，TS-28，Ku-28 でそれぞれ $4.4 \times$ $10^{-4}, 3.7 \times 10^{-4}, 1.7 \times 10^{-4} \mathrm{~g} / \mathrm{min} \cdot \mathrm{g}$ を示した。大谷 $ら^{4)}$ は SEM 観察から PF より TSの方が酸化反応性が 大きいととを報告して扣り,われわれの結果と異なって 


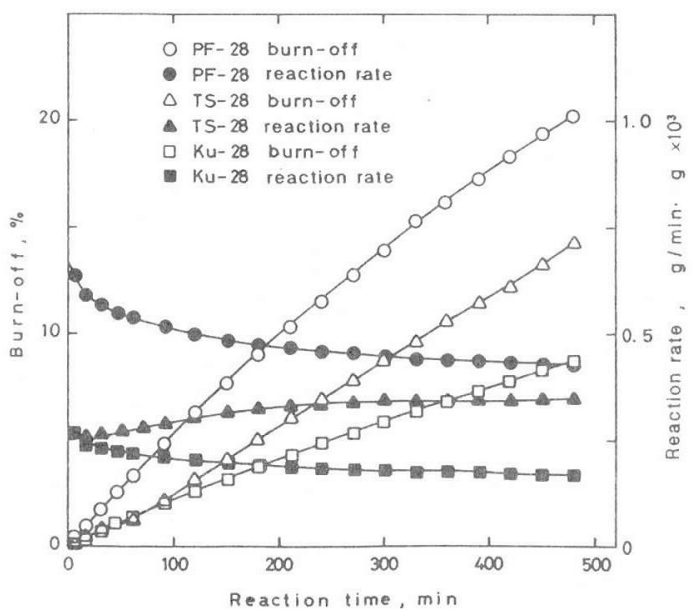

Fig. 3 Changes of burn-off and reaction rate with reaction time for carbons heattreated at $2800^{\circ} \mathrm{C}$.

いる。との相違については不明な点が多いが，大谷らの 比較的大きな試料の平滑表面での反応之本報告に扔ける 比較的微小な粒子状試料偟よる反応の相違が原因かもし れない。

\section{2 微細組織}

PF は典型的な難黑鉛化性炭素であり, Kuは典型的 な易黒鉛化性炭素である。それらの微細組織の特徽は既 亿報告6),7) しているように, PFがミクロポア組織を,

$\mathrm{Ku}$ がラメラ組織を示すととである。Fig. 4 亿 $1200^{\circ} \mathrm{C}$ 処 理試料の代表的な微細組織を示す。これから明らかなよ うに, ミクロポア組織の $\mathrm{PF}$ は直径 $2 \mathrm{~nm}$ 程度の気孔を あった多孔質で等方的な組織からできて扔り，発達した 積層構造は見られない。一方, ラメラ組織の $\mathrm{Ku}-12$ 亿招 いては大きさ約 $1 \mathrm{~nm}$ の炭素層面が, 平均 8 層程度まで 波打ちながら積み重なり, 一方向に配向している。先に 示した細孔容積の両者の相違は, この微細組織を反映し た結果であろう。PF-12 と Ku-12 の反応性の相違は, こ のような微細組織に基づく $\mathrm{CO}_{2}$ ガスの反応活性表面へ の接触の多少であることが推定できる。

$\mathrm{SEM}$ 観察からそれぞれの組織を反映した $\mathrm{CO}_{2}$ ガス反 応化伴う微粒子外形等の变化が見られる。すなわち, PF12は反応が進むにつれてはじめのガラス状表面から徐々 に荒い表面に変化してゆく。乙の変化は均一で,等方的 である。さらに反応が進行する之粒子表面はますます粗 くなり, 気孔は発達して直径20２00 nm の大きさにな る。一方, 異方性の強い $\mathrm{Ku}-12$ は, $\mathrm{CO}_{2}$ ガスによって はじめ端面が選択的に酸化され, 基底面に平行な外表面 はほ上んど变化が見られない。反応がかなり進行すると

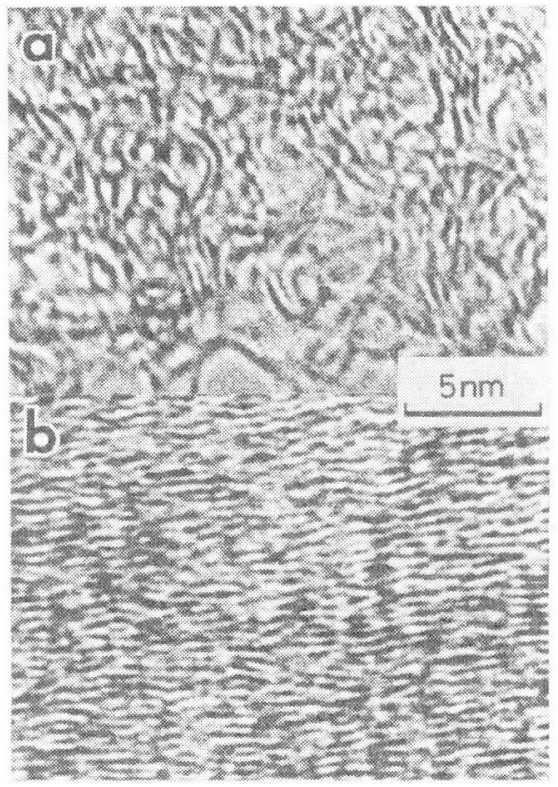

Fig. 4 Typical microtextures of original PF-12 (a) and Ku-12 (b).

基底面江平行な表面む粗くなるととがSEM 観察からわ かる。

PF-12 は数 $10 \mathrm{~nm}$ 以下の微小領域に打いて屯均一に反 応が進行し,SEM 観察で見られた反応に伴う表面の粗 さの進行は，気孔の発達によるととが TEM 観察からわ かった。Fig. 5a はPF-12の15\%酸化率の明視野像で あり, 直径 10 $30 \mathrm{~nm}$ の気孔が乱雑に分布している様 子がわかる。乙れを拡大すると, 反応前のミクロポア組 織が变化して一層瘦せた，開放的なそして曲がった炭素 層面が微細な気孔壁を形成していることか観察された。 さらに反応が進むと, bに示したように2 $6 \mathrm{~nm}$ の大き さの気孔が多くなり，積層がほとんど存在しなくなる。 すなわち, $\mathrm{CO}_{2}$ ガスとの反応の結果 PF-12 の微細組織 は等方的に変化し, ミクロポアを発達させて数 $\mathrm{nm}$ から $200 \mathrm{~nm}$ までの直径をむつ種々の気孔をむつ, より開放 的な組織沈なる。

一方，Ku-12では $\mathrm{CO}_{2}$ ガスとの反応によって Fig. 6a に示すように，積層間に10 40 nm の大きさの棈円状気 孔が発生する。この気孔は未反応の Ku-12 には見られ ない。薄い試料を観察すると, 基底面化平行で微粒子外 周部の近くでは酸化反応によって層面がまく机上がり， 層面間に気孔が発生していることがわかる。ての結果, 反応が進むにつれて積層の厚さは減少し, 反応が進んだ 領域ではbに示したように, 積層構造は全く消失して, 反応が進んだ PF-12の微細組織とほとんど区別できな 


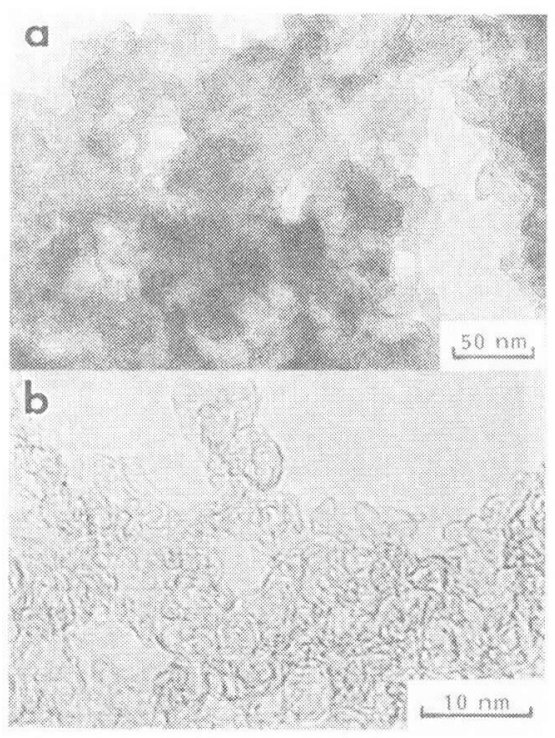

Fig. 5 TEM micrographs of PF-12 reacted at $900^{\circ} \mathrm{C}$.

a: $15 \%$ burn-off, b: $47 \%$ burn-off

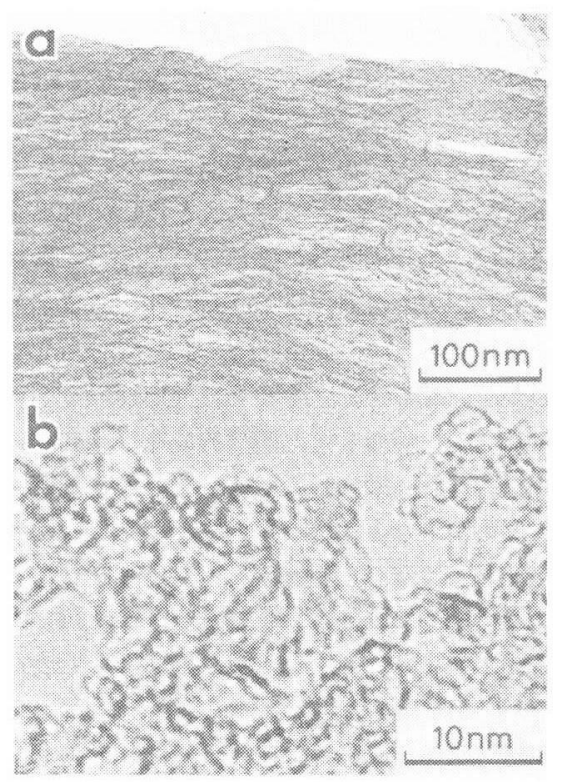

Fig. 6 TEM micrographs of $\mathrm{Ku}-12$ reacted at $900^{\circ} \mathrm{C}$ (23\% burn-off).

い瘦せた多孔質組織に変わった。とのように, Ku-12の 組織は酸化反応が進むとその異方性組織が消失し, 多孔 質な組織が残る。非常に反応が進んで多孔質組織になっ たときは、PF-12 と同程度の反応性をもつようになる と思わ机が。実際にはFig.2で見たようにKu-12の 反応速度が反応時間に伴って上昇する傾向はなかった。
この原因については現在のところ明らかでないが, 粒子 内での酸化反応がその組織を反映して均一に進行せず, 外表面は多孔質に变化した状態で屯, 内部では皘層構造 が残存することが一因かむし扎い。いず机してあ, $\mathrm{Ku}-12$ は端面での反応, 次いで層面間の反応に進んで積 層構造が乱机, 三次元的仅反応が進む。一方, PF-12 は はじめから三次元的に反応が進行する。このために Ku12はPF-12 亿比較して全体としての $\mathrm{CO}_{2}$ ガスによる反 応速度が小さいものと思われる。

Fig. 7 亿 $2800^{\circ} \mathrm{C}$ で処理した 3 種の炭素の TEM 像を 示す。PF-28はaに示したようにPF-12 と同様にミク

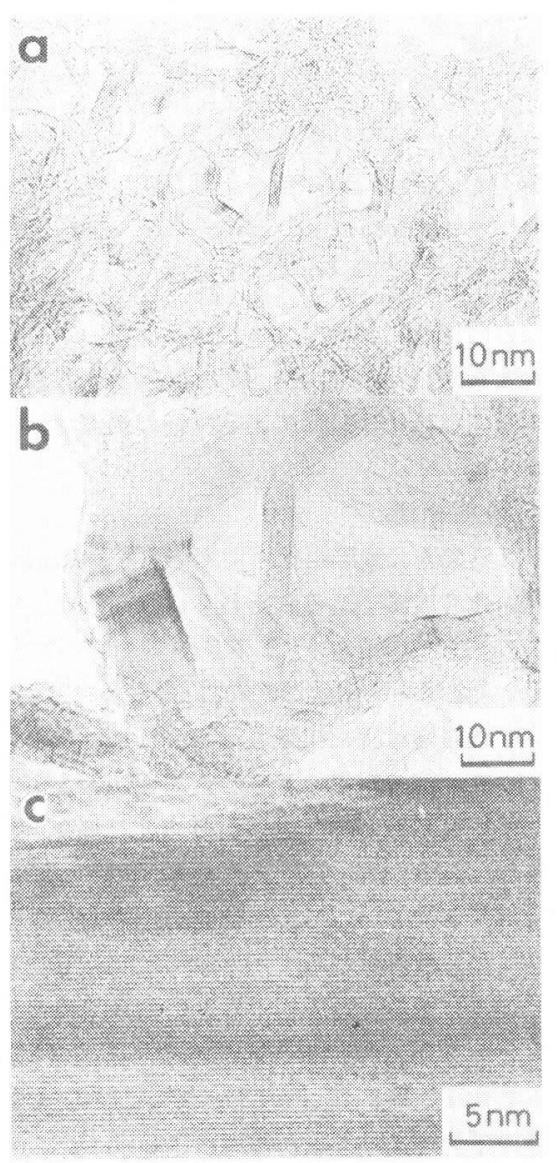

Fig. 7 Typical microtextures of original PF-28 (a), TS-28 (b) and Ku-28 (c).

ロポア組織を示すが、気孔がはっきりしてきて直径 6 $\mathrm{nm}$ 程度の大きさになると同時に, 積層がやや発達して 5〜8 層の炭素層面が積み重なるととが多い。これらの 值は Table 1 亿示したX 線パラメータの値とほぼ一致し ている。TSカーボンは高温処理によってもその構造が ほとんど変わらない炭素である5)。TS-28 では典型的な 
乱層構造を示し, TEM 観測では直径 $100 \mathrm{~nm}$ 程度の気孔 の周囲を炭素層面が壁を形成するマクロポア組織を示す。 積層はかなり発達して40層位まで観察されるが, 長距離 には発達せず,bに示したように折れ曲がった閉多角形 を形成する。Ku-28はc 亿示したように炭素層面は十分

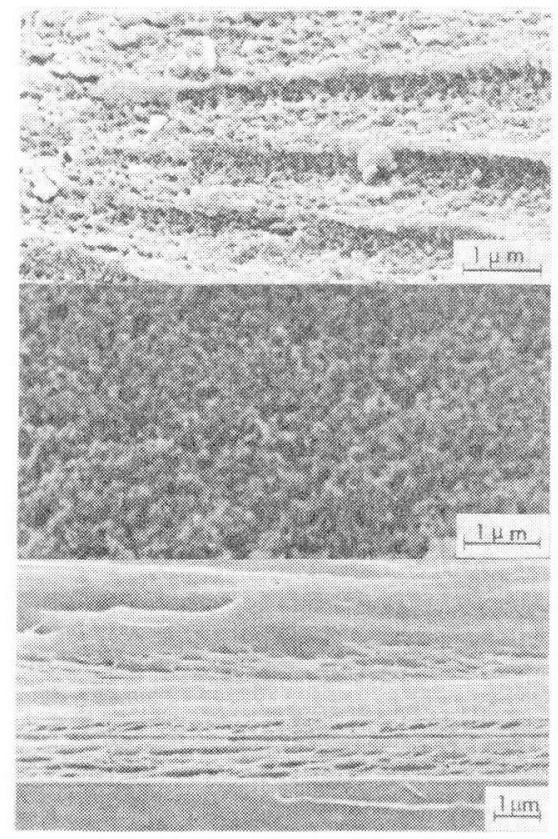

Fig. 8 SEM micrographs of carbons reacted at $900^{\circ} \mathrm{C}$.

a: PF-28, 10\% burn-off, b: TS-28, $14 \%$ burn off, c: Ku-28, 9\% burn off.
に大きくなり、積層構造がより発達した黒鉛結晶構造を あった炭素である。

SEM 観察の結果では, 反応前の PF-28は10 $\mu \mathrm{m}$ オー ダの視野では比較的平滑な平面をしているが, $1 \mu \mathrm{m}$ 以

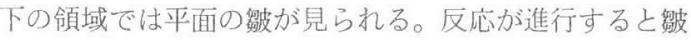
が消えて Fig. 8 a に示すように $1 \mu \mathrm{m}$ 以下の気孔が一面 に出現してくる。ての気孔分布は等方的で, 反応の進行 につれて気孔径が発達する。TS-28はPF-28より凹凸の ある表面をしている。20\%以下の酸化率では反応によ。 て顕著な外見上の変化は見ら机ないが，bに示したよう に0.2 $\mu \mathrm{m}$ 以下の気孔が発達する。また， $1 \mu \mathrm{m}$ 程度の気 孔が反応の進行につれてはっきりと現れてくる。Ku-28 については反応初期では微粒子外形にほとんど変化がな い。しかし，積層端面比おいて酸化率 $10 \%$ 以下でもc に見られるような細長い気孔が発達してくる。SEM 観 察で得られたてのような反応に伴う気孔の発生状況は 3 種の炭素の構造の特徵を反映したもので, PF, TS では 等方的に酸化されている様子が見られ，Kuに扔いては 基底面に平行な表面よりそれに垂直方向に $\mathrm{CO}_{2}$ ガスが 選択的に反応しているてとが知られる。

TEM による微細組織の反応に伴う变化の観察では, 積層構造の消失をよくとらえることができる。積層構造 の大きく発達していない多孔質な PF-28 では基本的な 組織は反応前後で変化しないが,Fig. 9b 亿見られるよ うに積層数が隇少し, 酸化率 $20 \%$ の とき平均 2 3 層に なっている。同時に炭素層面はより曲折して気孔壁がは っきりしなくなり, より開放的な構造に変化した。反応 前後に挹ける組織加ら，反応は等方的に進行した之考元

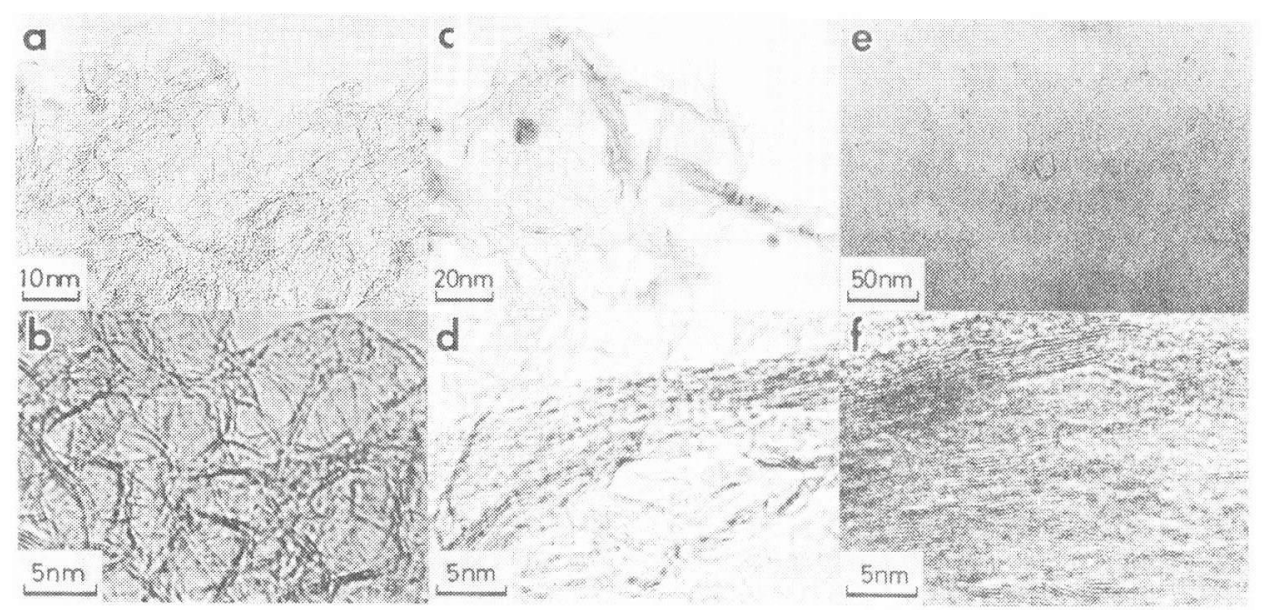

Fig. 9 TEM micrographs of carbons reacted at $900^{\circ} \mathrm{C}$. a: PF-28, 10\% burn-off, b: PF-28, 20\% burn-off, c: TS-28, $14 \%$ burn-off, d: TS-28, $14 \%$ burn-off, e: Ku-28, 7\% burn-off, f: Ku-28, 9\% burn-off. 
られる。TS-28では文心の進行に伴いc，dに見られるよ

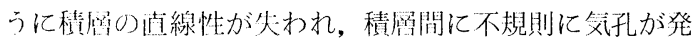

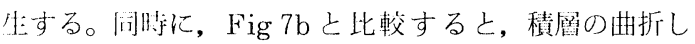
ている部分が優先的消失しているととが知られる。 Fig. 7bで積居が曲折している部分は連続しているよう に見えるが，直線状に延びた部分と比較すると， $\mathrm{CO}_{2}$ ガ ス分子が比較的異易に出人りできる程度の大きさの構造 の乱れがあることが仅応性の比較から推测できる。さら

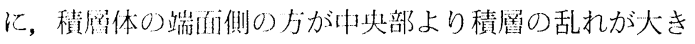
くなっているてとも知られ， $\mathrm{CO}_{2}$ ガスとの反応は, 端面 から進行しているととも推測できる。Ku-28 については 8ー9\%以トの酸化率では微細組織に大きな变化は見ら れないが, 端而の近傍で Fig.9f のように細長い4nm 程度の父孔が生じる。同時に炭素層面上に e 亿見られる ような20〜30 nm のやや角張ったピット状のものが見 られる。乙机は階段状化積み重なった炭素層面が, 端面

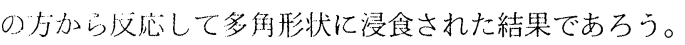
さらに文応が進むと長距離の積層構造は失われ, 積層間 に多くの父孔が発生し, 最終的には PFやTS の反応の 進んだ多孔質な組織とほとんど区別できない組織に変化 する。Table 2 亿微細組織の違いによる反応進行状況を 要約して小した。

Table 2 Reaction steps for lamellar and porous carbons.

\begin{tabular}{llc}
\hline Structure & Reaction & Reactivity \\
\hline lamellar & two steps & low \\
& $\begin{array}{l}\text { disintegration of layer } \\
\text { stacking (formation of } \\
\text { porous structure) } \\
\downarrow \\
\\
\\
\text { pore development } \\
\text { once through and } \\
\text { homogeneous } \\
\text { pore development }\end{array}$ \\
\end{tabular}

\section{3 ラマン分光}

$2800^{\circ} \mathrm{C}$ 処理試料の酸化率化伴うラマンスペクトルの 強度比 $\left(\mathrm{I}_{1360} / \mathrm{I}_{1580}\right)$ の関係を Fig.10亿示す。未反応 の強度比は PF-28で最も大きく, TS-28, Ku-28 と小さ くなり, この順溝造欠陥が減少しているてとを示して いる8!。乙れはX線パラメータや TEM の観察結果とも 一致している。強度比は反応の進行につれてPF-28で は酸化率 $5 \%$ 程度で大きく増大し, その後は飽和気味で ある。強度比が 1.7 位では積層構造を構成する炭素層面 の久陷量は非常に大きいもの之推定できる。TS-28や

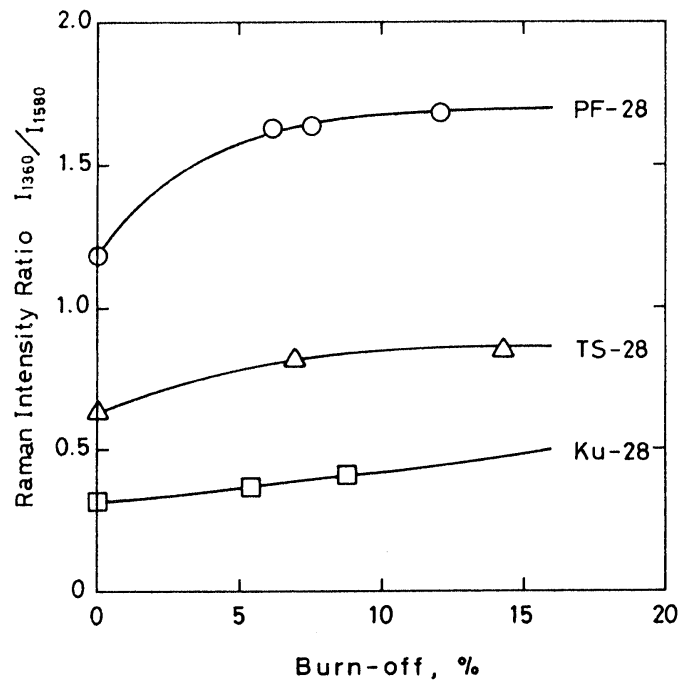

Fig. 10 Relation between Raman intensity ratio and burn-off for carbons reacted at $900^{\circ} \mathrm{C}$.

Ku-28 では反応につれて強度比が増大するが, 酸化率 20\%程度まででは PF-28の強度比の大きさには至らず, 炭素層面の崩壊は全体的に進んでいないてとがわかる。

TEM 像で反応が非常に進んだ状態ではTS- $28, \mathrm{Ku}$ 28が PF-28 と同様な多孔質組織を示すととを先に述べ たが，乙れは酸化後の TS-28, Ku-28の全体像を示し ているのではなく, 反応が優先的に進行する結晶子の端 面に㧍ける状態と考えるべきであるう。

\section{4. まと め}

$1200^{\circ} \mathrm{C}$ 抢よび $2800^{\circ} \mathrm{C}$ 亿熱処理した構造の異なる炭素 粉末を $900^{\circ} \mathrm{C}$ で $\mathrm{CO}_{2}$ ガスと度させ, その微細組織の 変化を観察した。その結果, 反応速度は多孔質組織で難 黒鉛化性の炭素 (PF) が最も大きく, 層状組織の発達 した易黑鉛化性の炭素（Ku）はPFの約60\%の反応速 度を示した。また, 乱層構造炭素 (TS-28) はPF と Ku の中間であった。 $\mathrm{PF}, \mathrm{Ku}$ については $2800^{\circ} \mathrm{C}$ 処理物の 反応速度は $1200^{\circ} \mathrm{C}$ 処理物のそれより小さく, 約 $40 \%$ で あった。乙れは高温度処理により積層構造が発達したて とと, PFについては開気孔の多くが閉気孔に変化したこ とによると思われる。反応はそれぞれの微細組織の特徵 を反映した進行の様子を示した。すなわち，PF は粒子 全体が等方的に反応し, 気孔を発達させてより積層数の 減少した開放的な組織に変化した。一方，Kuに打いて は, 反応は積層構造の端面から優先的に進行し, 層面間 に気孔を発生させて,さらに反応が進行すると積層構造 を崩壊させて多孔質組織になった。積層構造の崩壊を伴 
う反応速度は後段の多孔質組織における反応速度よりか なり小さいと思われる。乙れにより層状組織の Ku が多 孔質組織の PFより反応性が小さいことが理解できる。

$$
\text { 文献 }
$$

1) P.L. Waker Jr., F. Rusinko, Jr. and L.G. Austin, "Advances in Catalysis", Vol. 11, edited by D.D. Eley et al., Academic Press, New York (1959)

2) 今井 久, 「改定炭素材料入門」, 炭素材料学会編, P. 75

3) 鳥飼直親, 目黑竹司, 「多目的高温ガス実験炉用
黒鉛材料の調查」報告書, 日本学術振興会炭素材料 117 委員会, 昭和 57 年 9 月 p. 58

4) A. Oya, S. Jikihara and S. Otani, Fuel 62, 50 (1983)

5) 大谷杉郎, 大谷朝男, 西納峰吉, 炭素 1974 [No. 76] 2

6) 白石 稔, 樋口真次, 大塚良平, 燃協誌 65, 1004 (1986)

7) 白石 稔, 樋口真次, 大塚良平, ibid. 66, 55 (1987)

8) 中溝 実, 炭素 1977 [No. 90] 105

\section{炭素材料の可能性を追求する}

\section{CPC研究会編}

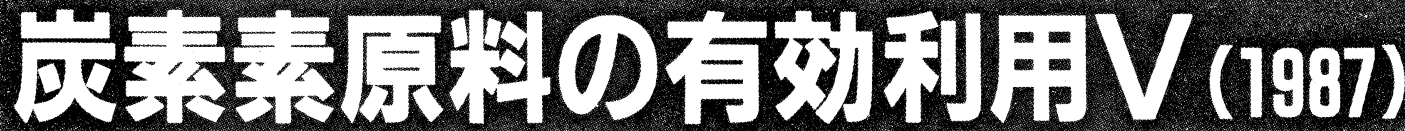

\section{第 1 霹 エネルギー}

1-1 CWMの分散安定化における 添加剂の効果

1-2 重質油および石炭の流動層熱 分解と副生炭素の利用

第 2 縉 石炭化学(工業)

2-1 水素原子によって誘起される 分解反応

2-2 水素移動からみた液化用石炭の 炭質および溶媒の特性評価

2-3 㛶とビチューメンとの混合処理

2-4 タールおよび石炭液化油から の化学原料

2-5 大量分取液体クロマトグラフ
イ一の現状と課題

第 3 編 炭素材料

3-1 ポリアセン系有機半導体の物性

3-2 メソカーボンマイクロビーズ

の丁.業的製造法

3-3 オーディオ用炭素製品——純

炭素スピーカ振動板—

第 4 編 炭亲織維と艺の複合材料

4-1 特許からみた炭素瀻維の最近 の動向

4-2 渦流法によるピッチ系炭素繊 維の製造

4-3 活性炭素瀻維 - P A N 系活性炭素繊維

\section{問合世株式会社} 注交先

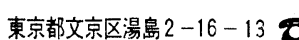

斉藤ビル $2 \mathrm{~F}$ T113 FAXOت (E15)ESES
アインガードを中心にしてー

4-4 P A N 系炭素緎維及びCFRP の技術動向!

—PPC研究会とは

CPCとはCoal, Petroleum and Cを 示す。最後のCはCo-Processing, Compatibility Carbonaceous mesophase, Coke, Carbonなどの䫒 交字のCであり, 不炭, 不油, 㵞青, 骸炭，炭素など，炭素質資源とその 処理に伴う変化と生成物とを意味し, すべての黑物の処理・利用を考える 研究会です。

発 刊 日 - 昭和62年 6 月 造本・体裁・B5版上製220頁 定価 15,000 円 